Well, M., Fischer, A., Jones, P. G., Schmutzler*, R.

$\rightarrow$ intramolekularer Donator-AkzeptorKomplexe mit der Phosphorylgruppe als Donator

Löwe, C., Shklover, V., Bosch, H. W., Berke*, H.

Schmid*, G., Gehrke, H., Kolorz, H.-U., Boese, R.

Küpper, S., Paetzold*, P., Boese, $\mathbf{R}$.

Sünkel*, K., Hofmann, G.

Friedrich, S., Gade*, L. H., Edwards, A. J., McPartlin, M.

Chemie des $\eta^{1}$-Rhenium-koordinierten Triphenylcyclopropenyl-Liganden

1781 Synthese und Komplexierung von Dithiatetrazadiborocinen

- Reaktionen der Borhydride $\mathrm{B}_{3} \mathrm{H}_{7}$ und $\mathrm{B}_{5} \mathrm{H}_{9}$ mit den ungesättigten Bor-Stickstoff-Verbindungen $\mathrm{NB} t \mathrm{Bu}_{2}$ und $\mathrm{NB}_{2} t \mathrm{Bu}_{3}$

1791 Koordinationschemie perhalogenierter Cyclopentadiene und Alkine, XV. - Systematischer Aufbau von fünffach ringsilylierten Cyclopentadienyl-mangan-Komplexen aus $\left[\mathrm{C}_{5} \mathrm{Br}_{5}\right] \mathrm{Mn}(\mathrm{CO})_{3}$. Molekülstruktur von $\left[\mathrm{C}_{5} \mathrm{Br}_{3}\left(\mathrm{SiMe}_{3}\right)_{2}\right] \mathrm{Mn}(\mathrm{CO})_{3}$

Strukturen, Beweglichkeit und Reaktivität von an $\mathrm{Ti}^{\mathrm{IV}}$-Zentren koordinierten tripodalen Aminoliganden

\section{Notiz / Note}

Weigand*, W., Robl, C.

Metallkomplexe mit funktionalisierten Schwefel-Liganden, VI. - Stabilisierung von 1-Alkin-1-thiolato-Liganden [R $\mathbf{C} \equiv \mathbf{C}-\mathbf{S}^{-} ; \mathbf{R}=\mathrm{SiMe}_{3},\left(\eta^{5}-\mathrm{C}_{5} \mathrm{H}_{4}\right) \mathrm{Fe}\left(\eta^{5}-\right.$ $\left.\mathrm{C}_{5} \mathrm{H}_{5}\right)$ ] in $\mathrm{Ru}(\mathrm{II})$ - und $\mathrm{Pt}(\mathrm{II})-\mathrm{Komplexen}$. Kristallstrukturanalyse von cis- $\left(\mathrm{Ph}_{3} \mathrm{P}\right)_{2}$ $\mathrm{Pt}\left[\mathrm{C} \equiv \mathrm{C}-\left(\eta^{5}-\mathrm{C}_{5} \mathrm{H}_{4}\right) \mathrm{Fe}\left(\eta^{5}-\mathrm{C}_{5} \mathrm{H}_{5}\right)\right]_{2}$

\section{Berichtigung / Correction}

Ostrowski, M., Jeske, J., Jones, P. G., du Mont*, W.-W.

Eigenschaften von Chalkogen-- Chalkogen-Bindungen, XVII. - Di- und Trisulfane mit sterisch anspruchsvollen AlkylSubstituenten: Das erste trans-Dialkyldisulfan

\section{Querverweise / Cross References}

Aumann, R.

Regitz*, M. et al.
Organische Synthesen mit Übergangsmetall-Komplexen, 64. - 1,4-Diaminonaphthaline über Ketenimin-Komplexe aus ( $\beta$ Aminovinylcarben)chrom-Komplexen und Isocyaniden

Organophosphorverbindungen, 71 . Phosphaalkine und Phosphaalkene als Abfangpartner für 1,2-Dehydrobenzol und Phenylium-2-carboxylat
Preparation and Structures of Some Intramolecular Donor-Acceptor Complexes with the Phosphoryl Group as Donor

Chemistry of the $\eta^{\prime}$-Rhenium-Coordinated Triphenylcyclopropenyl Ligand

Synthesis and Complexation of Dithiatetrazadiborocines

Reactions of the Boron Hydrides $\mathrm{B}_{3} \mathrm{H}_{7}$ and $\mathrm{B}_{5} \mathrm{H}_{9}$ with the Unsaturated Boron-Nitrogen Compounds $\mathrm{NB} t \mathrm{Bu}_{2}$ und $\mathrm{NB}_{2} t \mathrm{Bu}_{3}$

Coordination Chemistry of Perhalogenated Cyclopentadienes and Alkynes, XV. - Systematic Generation of Fivefold Ring-Silylated Cyclopentadienyl Manganese Complexes from $\left[\mathrm{C}_{5} \mathrm{Br}_{5}\right] \mathrm{Mn}(\mathrm{CO})_{3}$. Molecular Structure of $\left[\mathrm{C}_{5} \mathrm{Br}_{3}\left(\mathrm{SiMe}_{3}\right)_{2}\right]-$ $\mathrm{Mn}(\mathrm{CO})_{3}$

Structures, Dynamics, and Reactivity of Tripodal Amido Ligands Coordinated to $\mathrm{Ti}^{\mathrm{IV}}$ Centres

Metal Complexes of Functionalized Sulfur-Containing Ligands, VI. - Stabilization of 1-Alkyne-1-thiolato Ligands [ $R$ $\mathrm{C} \equiv \mathrm{C}-\mathrm{S}^{-} ; \mathrm{R}=\mathrm{SiMe}_{3},\left(\eta^{5}-\mathrm{C}_{5} \mathrm{H}_{4}\right) \mathrm{Fe}\left(\eta^{5}-\right.$ $\left.\left.\mathrm{C}_{5} \mathrm{H}_{5}\right)\right]$ in $\mathrm{Ru}(\mathrm{II})$ - and $\mathrm{Pt}(\mathrm{II})$-Complexes. Xray Structure Analysis of cis- $\left(\mathrm{Ph}_{3} \mathrm{P}\right)_{2^{-}}$ $\mathrm{Pt}\left[\mathrm{C} \equiv \mathrm{C}-\left(\eta^{5}-\mathrm{C}_{5} \mathrm{H}_{4}\right) \mathrm{Fe}\left(\eta^{5}-\mathrm{C}_{5} \mathrm{H}_{5}\right)\right]_{2}$

Properties of Chalcogen-Chalcogen Bonds, XVII. - Di- and Trisulfanes with Sterically Congested Alkyl Substituents: The first trans-Dialkyldisulfane

Organic Syntheses via Transition Metal Complexes, 64. - 1,4-Diaminonaphthalines via Ketenimine Complexes from ( $\beta$ Aminovinylcarbene)chromium Complexes and Isocyanides

Organophosphorus Compounds, 71. Phosphaalkynes and Phosphaalkenes as Trapping Partners for 1,2-Dehydrobenzene and Phenylium-2-carboxylate 
Shinmyozu*, T., Kusumoto, S., Nomura, S., Kawase, H., Inazu, $\mathrm{T}$.

Mataka*, S., Irie, T., Ikezaki, Y., Tashiro, M. Maier*, G., Wilmes, R.

Maier*, G., Wilmes, R., Fuchs, H., Leinweber, M.

Bata, I., Korbonits*, D., Kolonits, P., Podányi, B., Takácsy-Erös, T., Simon, K.

Griesbaum*, K., Schlindwein, K., Hilß, M.

Köbbing, S., Mattay*, J., Raabe, G.

Glocker, M. O.

Shrestha-Davadi, P. B.,

Küchler-Krischun, J., Hofmann, J., Fischer, H., Jochims*, J. C.

Aumann, R.

Boche*, G., Bosold, F., Lohrenz, J. C. W., Opel, A., Zulauf, P.

Boche*, G., Marsch, M., Harbach, J., Harms, K., Ledig, B., Schubert, F., Lohrenz, J. C. W., Ahlbrecht, H.

Hock, R., Hillenbrand, S., Erker*, G., Krüger, C., Werner, $\mathrm{S}$.

Ipaktschi*, J., Heydari, A.

Mayr*, H., Heigl, U. W., Baran, J.

Korth*, H.-G., Sustmann, R., Sicking, W., Klärner, F.-G., Tashtoush, H. I.

1815

\section{3}

Ozonide von acyclischen Olefinen mit mono- und dichlorsubstituierten Doppelbindungen

Cycloadditionen, 43. - Cyclobutanone über Photoreaktionen von Chrom-Carben-Komplexen mit Olefinen und Dienen - Ein Vergleich mit der herkömmlichen Keten-Methode

Über die Reaktionen von Nitrilium- und $\mathrm{N}$-Acylamidinium-Salzen mit Oximen und anderen Hetero-Nucleophilen

Organische Synthesen mit Übergangsmetall-Komplexen, 64. - 1,4-Diaminonaphthaline über Ketenimin-Komplexe aus ( $\beta$ Aminovinylcarben)chrom-Komplexen und Isocyaniden

$\alpha$-Sauerstoff-substituierte lithiumorganische Verbindungen und ihre CarbenoidNatur: Reaktionen mit RLi und anderen Nucleophilen, experimentelle und IGLOberechnete ${ }^{13} \mathrm{C}$-NMR-Verschiebungen des Carbenoid-C-Atoms

[ $\alpha$-(Dimethylamino)benzyllithium Diethylether $]_{2}, \quad(S)-\alpha-($ Methylpivaloylamino)benzyllithium - (-)-Spartein und [3-Iod2-lithio-1-methylindol-2 Tetrahydrofuran $]_{2}$ : Kristallstrukturuntersuchungen von $\alpha$-lithiierten Aminen

Dihydroselenapyrane durch $[4+2]-\mathrm{Cy}-$ cloaddition von Diarylselenoketonen

- $\mathrm{LiClO}_{4}$-katalysierte nucleophile Addition an $\alpha$-chirale Aldehyde, Aldimine und Oxirane

Eine schrittweise $[4+3]$-Cycloadditionsreaktion des 1,3-Diphenyl-2-azaallyl-Anions

1917 Umlagerungen freier Radikale, XIII. Thermische und photochemische Umlagerungen von cyclischen $\mathrm{C}_{8} \mathrm{H}_{9}$-Radikalen in Adamantan-Matrix

- Publikationssprache
Multibridged $\left[3_{n}\right]$ Cyclophanes, 1. - Synthesis of $\left[3_{4}\right](1,2,3,5)$ - and $-(1,2,4,5)$ Cyclophanes

Preparation of Benzo-diimidazoles and Benzo-triimidazoles

Small Rings, 76. - Intermediates on the Way to Tetramethyl Cyclopentadienonetetracarboxylate

Small Rings, 77. - Generation and Trapping Reactions of Tetramethyl Cyclobutadienetetracarboxylate

- Synthesis of 4-Aminopyrimidines from 1,2,4-Oxadiazoles, V. - Reductive Formation of 2-Benzoylamino)indole from 3(2-Aminobenzyl)-5-phenyl-1,2,4-oxadiazole and Its Transformation to 6-Phenyl-8Hpyrimido[1,6- $\left.a: 4,5-b^{\prime}\right]$ diindole, a New Heterocyclic Ring System

Ozonides of Acyclic Olefins Having Mono- and Dichloro-Substituted Double Bonds

Cycloadditions, 43. - Cyclobutanones via Photoreactions of Chromium-Carbene Complexes with Olefins and Dienes - A Comparison with the Traditional Ketene Method

On the Reaction of Nitrilium and $N$-Acylamidinium Salts with Oximes and Other Hetero Nucleophiles

Organic Syntheses via Transition Metal Complexes, 64. - 1,4-Diaminonaphthalines via Ketenimine Complexes from ( $\beta$ Aminovinylcarbene)chromium Complexes and Isocyanides

$\alpha$-Oxygen-Substituted Organolithium Compounds and their Carbenoid Nature: Reactions with RLi and Other Nucleophiles, Experimental and IGLO-Calculated ${ }^{13} \mathrm{C}$-NMR Shifts of the Carbenoid C Atom

[ $\alpha$-(Dimethylamino)benzyllithium - Diethyl Ether $]_{2},(S)-\alpha$-Methylpivaloylamino)benzyllithium - $(-)$-Sparteine, and [3-Iodo2-lithio-1-methylindole-2 Tetrahydrofuran $]_{2}$ : Crystal Structure Investigations of $\alpha$-Lithiated Amines

- Dihydroselenapyrans by $[4+2]$ Cycloaddition of Diaryl Selenoketones

$\mathrm{LiClO}_{4}$-Catalyzed Nucleophilic Addition to $\alpha$-Chiral Aldehydes, Aldimines, and Oxiranes

- A Stepwise [4 + 3] Cycloaddition Reaction of the 1,3-Diphenyl-2-azaallyl Anion

Rearrangements of Free Radicals, XIII. Thermal and Photochemical Rearrangements of Cyclic $\mathrm{C}_{8} \mathrm{H}_{9}$ Radicals in Adamantane Matrix

- Language of Publication 


\section{Inhalt (Fortsetzung)}

Enders*, D., Scherer, H. J., Runsink, J.

Breit, B., Regitz*, M.

Notizen / Notes

Perjési*, P., Batta, G.

Bott, $\mathbf{K}$.

Bingel, C.
1951

Beziehung zwischen dominanter Konformation und Diastereoselektivität der $O$ Acetal-Bildung von gesättigten $2 \mathrm{H}-3,1-$ Benzothiazin-2-thionen

1955

Alkylierungsreaktionen mit Alkoholen und Kohlenmonoxid: Eine breit anwendbare Synthese von Thioethern und von Coffein aus Theophyllin

1929 Diastereo- und enantioselektive Synthese 1,2-trans-substituierter Cycloalkancarbonsäureester und Sulfone durch Michael-initiierte Cyclisierungen via SAMP-/RAMPHydrazone

1945 Organophosphorverbindungen, 71. Phosphaalkine und Phosphaalkene als Abfangpartner für 1,2-Dehydrobenzol und Phenylium-2-carboxylat

- Publikationssprache
1957 Cyclopropanierung von Fullerenen

\section{Contents (Continued)}

Diastereo- and Enantioselective Synthesis of 1,2-trans-substituted Cycloalkanecarboxylates and Sulfones by Michael-Initiated Cyclisation via SAMP/RAMP Hydrazones

Organophosphorus Compounds, 71. Phosphaalkynes and Phosphaalkenes as Trapping Partners for 1,2-Dehydrobenzene and Phenylium-2-carboxylate

Relationship between Dominant Conformation and Diastereoselectivity of $O$-Acetal Formation of Saturated 2H-3,1-Benzothiazine-2-thiones

Alkylation Reactions by Means of Alkanols and Carbon Monoxide: An Efficient Synthesis of Thioethers and of Caffeine from Theophylline

Cyclopropylation of Fullerenes
- Language of Publication 


\title{
A Stepwise [4 + 3] Cycloaddition Reaction of the 1,3-Diphenyl-2-azaallyl Anion ${ }^{2 / 3}$
}

\author{
Herbert Mayr* ${ }^{* 1 \neq}$, Ulrich W. Heigl ${ }^{a}$, and Janusz Baran ${ }^{b}$ \\ Institut für Chemie der Medizinischen Universität zu Lübeck ${ }^{a}$, \\ Ratzeburger Allee 160, D-23562 Lübeck, Federal Republik of Germany \\ Institute of Fundamental Chemistry, Technical University ${ }^{b}$, \\ Al. Piastów 42, PL-71-065 Szczecin, Poland
}

Received March 10, 1993

Key Words: 2-Azaallyl anion, 1,3-diphenyl / $[4+3]$ Cycloaddition / Concertedness / Pyrrolidines / Azepine, tetrahydro-

The 1,3-diphenyl-2-azaallyl anion (1) undergoes [3 +2$]$ cycloaddition reactions with the s-cis-fixed 1,3-dienes 8-11. In contrast, 1,1,2,2,3,3-hexamethyl-4,5-bis(methylene)cyclopentane (7) reacts with 1 to give the [4+3] cycloadduct 13 and the linear 1,4-addition product 14. This reaction is four orders of magnitude slower than the corresponding reaction of 1 with 1,2-bis(methylene)cyclopentane (8), which exclusively yields $[3+2]$ cycloadducts. A change of mechanism - concerted cycloaddition of 8 and stepwise cycloaddition of $\mathbf{7}$ - is suggested, but not unequivocally proven. It is concluded that reactions of 1 with ordinary dienes cannot profit from concertedness by more than $5 \mathrm{kcal} \cdot \mathrm{mol}^{-1}$.
Cycloadditions of allyl anions to $\mathrm{CC}$ double bonds (eq. 1), have been classified as orbital symmetry-allowed $\left[{ }_{\pi} 4_{s}+{ }_{\pi} 2_{s}\right]$ processes by Woodward and Hoffmann ${ }^{[1]}$.

$$
\langle\theta+\| \longrightarrow \theta\rangle
$$

Prior to the experimental realization of this reaction ${ }^{[2]}$, analogous cycloadditions of 2-azaallyl anions have been reported. In accord with a concerted process, Kauffmann et al. found stereospecific cycloaddition of 1,3-diphenyl-2azaallyl anion (1) to $(E, Z)$-isomeric alkenes with retention of configuration of the alkene and of the azaallyl anion moiety (Scheme 1) ${ }^{[3]}$. The mechanistic impact of this observation has been questioned ${ }^{[4]}$, however, because the isolated yield of cycloadducts was rather low [ $21 \%$ with $(Z)$-stilbene (2b)].

\section{Scheme 1}

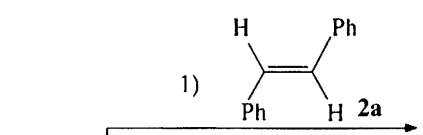

2) $\mathrm{H}_{2} \mathrm{O}$

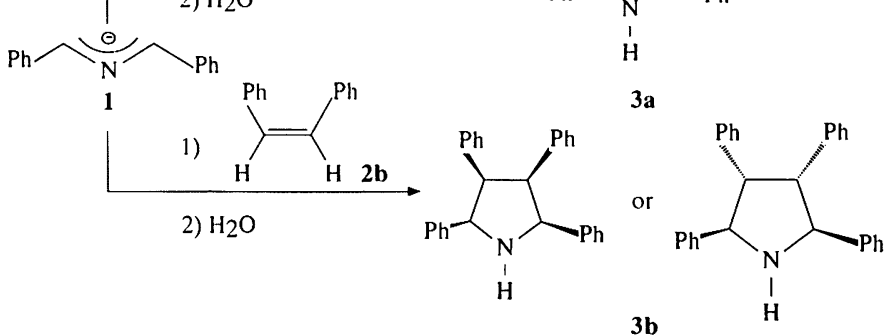

3b

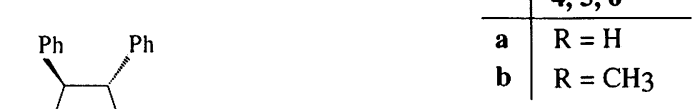

Cycloheptatriene, on the other hand, reacts with 1,1- and 1,3-diphenylazaallyl anion to give exclusively $[6+3]$ cycloaddition products ${ }^{[6]}$, in accord with an orbital symmetryallowed $\left[\pi 4_{s}+{ }_{\pi} 6_{s}\right]$ process.

Recently, we have demonstrated that the s-cis-fixed diene 7 can be used as a probe for the study of cycloaddition mechanisms ${ }^{[7]}$. Since the nonterminal positions of the diene fragment of 7 are sterically shielded, 1,4-additions have been observed even with such cycloaddends which generally undergo 1,2-additions with ordinary dienes (carbenes ${ }^{[7 b]}$, ketenes $^{[7 \mathrm{c}]}$, nitrones ${ }^{[7 \mathrm{~d}, \mathrm{c}]}, 1,3$-dienes $\left.{ }^{[7 \mathrm{7f}}\right)^{[1,8]}$. We have now in-

[] New address: Institut für Organische Chemie, Technische Hochschule Darmstadt, Petersenstraße 22, D-64287 Darmstadt, Federal Republic of Germany.
Further evidence for a concerted pathway has been derived from the exclusive formation of vinylpyrrolidines 5 obtained by reaction of $\mathbf{1}$ with 1,3-butadiene (4a) and iso(4b) $)^{[5]}$. There is no evidence for the formation of a tetrahydroazepine $\mathbf{6}$, which might have been generated by a
stepwise pathway since its formation by a concerted cycloaddition reaction is orbital symmetry-forbidden (Scheme 2).

Scheme 2

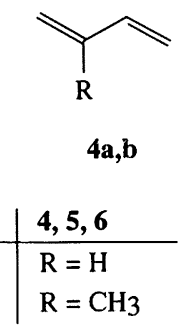

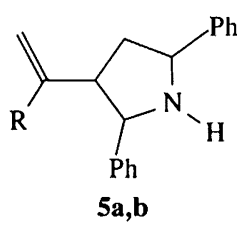

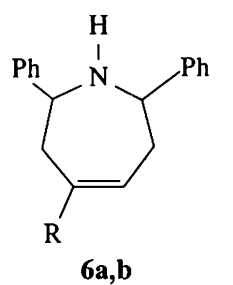

Chem. Ber. 1993, 126, 1913-1916 C) VCH Verlagsgesellschaft mbH, D-69451 Weinheim, 1993 0009-2940/93/0808-1913 \$10.00+.25/0 
vestigated the reaction of $\mathbf{1}$ with 7 and other s-cis-fixed dienes $(8-12)$ and present the first observation of a [4 +3$]$ cycloaddition product with an azaallyl anion.

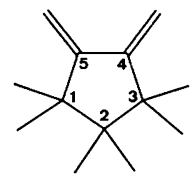

7

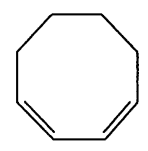

10

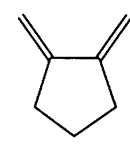

8

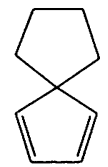

11

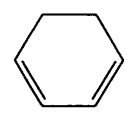

9

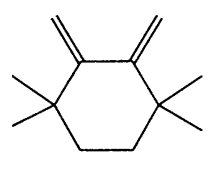

12

\section{Results}

When 1,3-diphenyl-2-azaallyllithium $\left(1-\mathrm{Li}^{+}\right)$, prepared from $N$-benzylidenebenzylamine and LDA (1.1 equiv.), was allowed to react with diene 7 in THF for four days at room temperature, the crystalline compound $\mathbf{1 3}$ was isolated in $47-52 \%$ yield after aqueous workup. The ${ }^{13} \mathrm{C}$-NMR spectrum of 13 shows the presence of four different methyl resonances, in accord with the cis-arrangement of the two phenyl groups. Analysis of the mother liquors by GC/MS indicated the presence of five more compounds with $\mathrm{M}^{+}=373(0.5-7 \%$ yield $)$.

A different reaction course was observed, however, when moisture was not rigorously excluded from the reaction mixture. The yield of the cycloadduct 13 decreased to $10-30 \%$ while 14, one of the side products mentioned above, became the main product (Scheme 3). Up to $36 \%$ yield of $\mathbf{1 4}$ was isolated, when $N$-benzylidenebenzylamine was deprotonated in a THF solution containing 1.5 equiv. of LDA and 0.3 equiv. of water. The suggested structure of $\mathbf{1 4}$ was in accord with the ${ }^{1} \mathrm{H}-\mathrm{NMR}$ signal at $\delta=8.18(1 \mathrm{H})$ and the observation of 7 methyl signals in the ${ }^{13} \mathrm{C}$-NMR spectrum. An interconversion between 13 and 14 by treatment of either compound with LDA under the reaction conditions was not observed.

\section{Scheme 3}

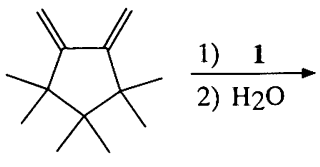

7

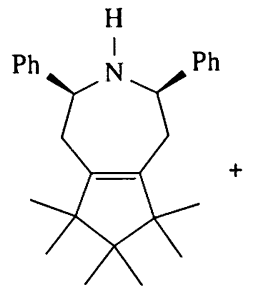

13

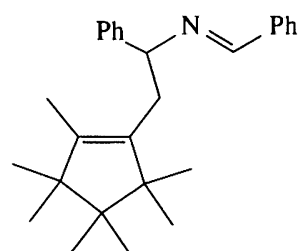

14
Analogous reactions of $\mathbf{1}$ with the s-cis-fixed dienes $\mathbf{8 , 9}$, and $\mathbf{1 0}$ gave mixtures of products, from which the regular $[3+2]$ cycloadducts $15, \mathbf{1 6}$, and 17 were isolated in 86,47 , and $41 \%$ yield, respectively. The reaction with diene 8 gave a 2:1 mixture of two diastereoisomers of $\mathbf{1 5}$, from which only the main component was isolated in pure form. The stereochemistry of this compound and of 16-18 was not determined. Diene 11 did not react with 1 at room temperature, but upon heating at $65^{\circ} \mathrm{C}$ the $[3+2]$ cycloadduct 18 was produced in $9 \%$ yield. We were not able to obtain a reaction product from diene 12 , probably because nonplanarity of the $\pi$ system (dihedral angle according to MMP 2: $54^{\circ}$ ) and steric shielding of the methyl groups conjoin to reduce the reactivity of $\mathbf{1 2}$.

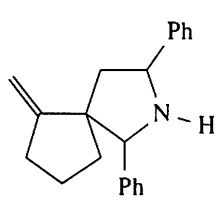

15

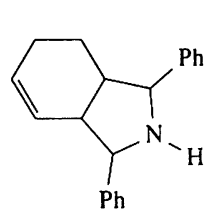

16

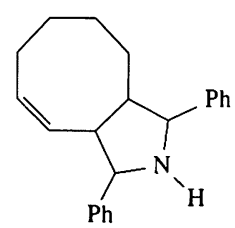

17<smiles>C1=CC2(CCCC2)C2C(c3ccccc3)NC(c3ccccc3)C12</smiles>

18

\section{Discussion}

Compound 7 was the only 1,3-diene investigated, which gave rise to the formation of a $[4+3]$ cycloadduct. A stepwise cycloaddition mechanism, as suggested by the orbital symmetry rules, was supported by the isolation of compound 14, a trapping product of the intermediate 19a (Scheme 4). As reported above, the formation of compound 14 was only observed, when some water was present in the reaction mixture. Since water is deprotonated by LDA in this solution, we assume that protonation of 19a takes place within an aggregate of $\mathrm{LiOH}$ with $19 \mathrm{a}-\mathrm{Li}^{+}$. Diisopropylamine cannot be responsible for the protonation of $19 a$, as 14 was not formed in significant amounts, when the reaction of 1 with 7 was carried out in anhydrous THF in the presence of 5 equiv. of $\mathrm{HN}(i \operatorname{Pr})_{2}$.

Scheme 4

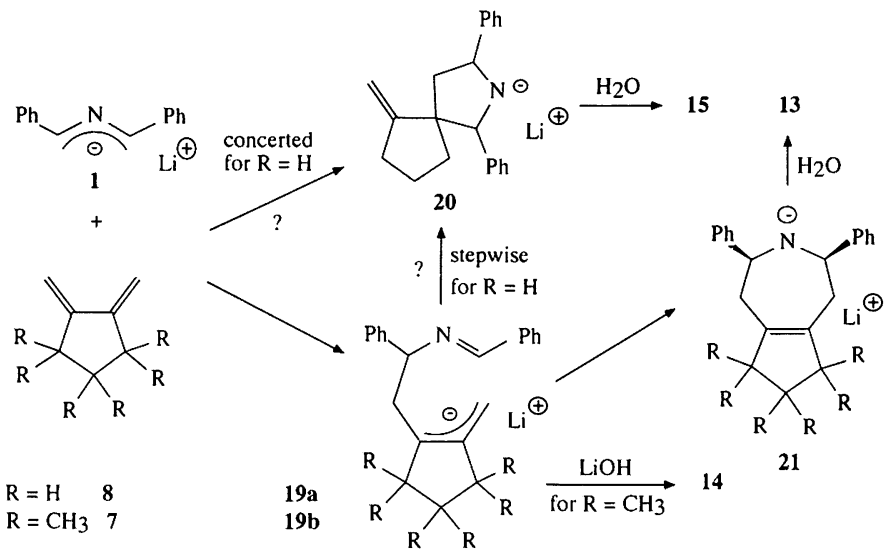

The formation of different types of products from the dienes $\mathbf{7}$ and $\mathbf{8}$ can be explained in two different ways. Possibly both dienes undergo stepwise cycloadditions via the intermediates 19a, b (Scheme 4), and cyclization of 19 to a five-membered ring is only possible for $\mathrm{R}=\mathrm{H}$. In the case of $\mathrm{R}=\mathrm{CH}_{3}$ steric shielding might inhibit this cyclization resulting in the formation of $\mathbf{1 3}$ and/or $\mathbf{1 4 .}$ 
Alternatively, one might assume that $\mathbf{8}$ undergoes a concerted cycloaddition, which is inhibited by the steric bulkiness of the methyl groups in 7. Consequently, the diene 7 has to react via $19 \mathrm{~b}$, which is expected to yield products 13 and $\mathbf{1 4}$ for the reasons discussed above.

In a previous review ${ }^{[7 a]}$, we have discussed that these two possibilities might be distinguished by kinetic experiments. If both, methylated and nonmethylated diene 7 and 8 , reacted stepwise, similar rates would be expected for both reactions, since in the rate-determining step (formation of 19) the steric effect of the methyl groups is not yet realized ${ }^{[7]}$. On the other hand, if a concerted mechanism was assumed to account for the formation of the $[3+2]$ cycloadduct, the steric effect of the methyl groups would become effective in the rate-determining step, and $\mathbf{7}$ should react more slowly than 8 . The different types of products obtained from 7 and 8 would indicate that the methyl groups in 7 raise the barrier for the concerted cycloadditions sufficiently, so that the stepwise mechanism via 19 becomes enforced.

Kinetic investigations of the reaction of $1-\mathrm{Li}^{+}$with 7 and 8 in THF at $24.5^{\circ} \mathrm{C}$ gave second-order rate constants of $k_{2}(7)=(6.08 \pm 0.24) \cdot 10^{-5} 1 \mathrm{~mol}^{-1} \mathrm{~s}^{-1}$ and $k_{2}(8)=(5.1 \pm$ $0.3) \cdot 10^{-1} 1 \mathrm{~mol}^{-1} \mathrm{~s}^{-1}$. This reactivity ratio is considerably greater than that for the analogous nitrone ${ }^{[7 \mathrm{dd.c]}}$ or nitrile oxide $^{[9]}$ cycloadditions suggesting that a change from the concerted (8) to the stepwise (7) mechanism is taking place. This conclusion is not absolutely sure, however, since the different reaction rates of $\mathbf{7}$ and $\mathbf{8}$ may partially be due to the hyperconjugative electron-donating effect of the additional methyl groups in 7 , which might slow down the reactions with anionic reaction partners. Concertedness for the reaction of 1 with 8 can thus not be proven. Since compound 8 can be considered as a typical diene, however, we can conclude that reactions of the azaallyl anion 1 with ordinary dienes cannot profit from concertedness by more than $5 \mathrm{kcal} \cdot \mathrm{mol}^{-1}$, i.e., the observed difference in activation free enthalpies for $\mathbf{7}$ and $\mathbf{8}$.

We thank the Deutsche Forschungsgemeinschaft (Ma 673/8-1,2) and the Fonds der Chemischen Industrie for financial support.

\section{Experimental}

IR: Shimadzu IR-435 spectrometer. - NMR (200 MHz): Varian $\mathrm{XL} 200$ spectrometer, tetramethylsilane as internal standard, $\mathrm{CDCl}_{3}$ as a solvent. - MS (EI): 70-250E VG spectrometer. - Microanalyses: Ilse Beetz, Microanalytisches Laboratorium, D-8640 Kronach, Germany. - Melting points: uncorrected. - GC analyses: Carlo Erba GC 6000 gas chromatograph equipped with FID. Preparative MPLC separations: $30 \times 2.5-\mathrm{cm}$ columns filled with LiChroprep (RP-18 or Si 60, 15-20- $\mu$ m particles).

Substrates: Dienes 9 and $\mathbf{1 0}$ were commercially available and used freshly distilled. Compounds $7^{[10]}, \mathbf{8}^{[11]}$, and $11^{[12]}$ were prepared according to literature procedures, and 1,1,4,4-tetramethyl-2,3-bis(methylene)cyclohexane (12) was obtained by treatment of 1,2-bis(bromomethyl)-3,3,6,6-tetramethyl-1-cyclohexene ${ }^{[13]}$ with $\mathrm{Mg}$ as described for $7^{[10]}$. 1,3-Diphenyl-2-azaallyllithium $\left(1-\mathrm{Li}^{+}\right)$was prepared in THF solution by deprotonation of $\mathrm{N}$-benzylidenebenzylamine ${ }^{[14]}$ with LDA according to ref. ${ }^{[3]}$ Diisopropylamine and THF were freshly distilled over $\mathrm{LiAlH}_{4}$.
Reaction of 1,3-Diphenyl-2-azaallyl Anion (1) with Diene 7 (Standard Procedure): The reaction was performed in an oven-dried flask under nitrogen at room temp. Diisopropylamine (1.24 g, $12.4 \mathrm{mmol})$ in $5 \mathrm{ml}$ of THF was added to a $1.6 \mathrm{M}$ solution of $\mathrm{BuLi}$ in hexane $(7.1 \mathrm{ml}, 11.3 \mathrm{mmol})$. The LDA solution thus obtained was stirred for a few $\mathrm{min}$, and after the addition $(2 \mathrm{~min})$ of $\mathrm{N}$-benzylidenebenzylamine $(2.0 \mathrm{~g}, 10.25 \mathrm{mmol})$ in THF $(5 \mathrm{ml})$ the deep purple-red solution of 1 was stirred for $0.5 \mathrm{~h}$. Diene $7(1.83 \mathrm{~g}, 10.25 \mathrm{mmol})$ in $5 \mathrm{ml}$ of THF was subsequently added, and the reaction mixture was stirred at ambient temp. for $4 \mathrm{~d}$. Water was then added, and the mixture was extracted with five $20-\mathrm{ml}$ portions of ether. The combined ether extracts were dried with sodium carbonate, and after removal of the solvents under reduced pressure, methanol was added to the yellow residue. The precipitate was collected by filtration and washed with methanol to give a colorless product which was recrystallized from pentane: $13(1.70 \mathrm{~g}, 47 \%)$.

8,8,9,9,10,10-Hexamethyl-3,5-diphenyl-4-azabicyclo[5.3.0]dec1(7)-ene (13): m.p. (pentane) $180.5-181^{\circ} \mathrm{C}$. - IR (KBr): $\tilde{v}=3426$ $\mathrm{cm}^{-1}$ (br. NH). - ' $\mathrm{H} \mathrm{NMR}\left(\mathrm{CDCl}_{3}\right): \delta=0.78\left(\mathrm{~s}, 3 \mathrm{H}, \mathrm{CH}_{3}\right), 0.80$ (s, $\left.6 \mathrm{H}, 2 \mathrm{CH}_{3}\right), 0.86\left(\mathrm{~s}, 3 \mathrm{H}, \mathrm{CH}_{3}\right), 0.98\left(\mathrm{~s}, 6 \mathrm{H}, 2 \mathrm{CH}_{3}\right), 2.00$ (br. s, $1 \mathrm{H}$, $\mathrm{NH}), \mathrm{ABM}$ system with $v_{\mathrm{A}}=2.19, v_{\mathrm{B}}=2.55, v_{\mathrm{M}}=3.66$, and $J_{\mathrm{AB}}=15.0, J_{\mathrm{AM}}=9.8, J_{\mathrm{BM}}=3.0 \mathrm{~Hz}$, further split by long-range couplings $(6 \mathrm{H}, 2,6-\mathrm{H}, 3,5-\mathrm{H}), 7.26(\mathrm{~m}, 10 \mathrm{H}$, arom. $\mathrm{H}) .-{ }^{13} \mathrm{C} \mathrm{NMR}$ $\left(\mathrm{CDCl}_{3}\right): \delta=20.96\left(\mathrm{q}, \mathrm{CH}_{3}\right), 22.57\left(\mathrm{q}, \mathrm{CH}_{3}\right), 23.58\left(\mathrm{q}, 2 \mathrm{CH}_{3}\right), 25.06$ (q, $\left.2 \mathrm{CH}_{3}\right), 36.99$ (t, C-2,6), 45.73 (s, C-9), 50.37 (s, C-8,10), 65.15 (d, C-3,5), 126.53 (d), 127.05 (d), 128.44 (d), 141.15 (s), 146.83 (s, C-1,7). - MS (70 eV), m/z (\%): 373 (12) [ $\left.\mathrm{M}^{+}\right], 195$ (100), 194 (93), 91 (11). $-\mathrm{C}_{27} \mathrm{H}_{35} \mathrm{~N}$ (373.6): calcd. C 86.81, H 9.44, N 3.75; found C 86.81, $\mathrm{H} 9.38$, N 3.83 .

Reaction of Diene 7 with 1 in the Presence of Water: The reaction was carried out according to the general procedure, but with an excess of LDA (LDA: $6.7 \mathrm{mmol}$; $N$-benzylidenebenzylamine: $1.0 \mathrm{~g}$, $5.1 \mathrm{mmol}$; 7: $0.91 \mathrm{~g}, 5.1 \mathrm{mmol})$. Moreover, before the addition of benzylidenebenzylamine, water $(0.027 \mathrm{~g}, 1.5 \mathrm{mmol})$ was injected into the reaction mixture. Compounds 13 and $\mathbf{1 4}(1: 2.5$, determined by GC and 'H-NMR analysis) were formed together with traces of other compounds, and $36 \%$ of 14 was isolated by preparative LC (RP18; $\mathrm{McOH})$. Compound 13 was not eluted under these conditions.

1-(2,4-Diphenyl-3-aza-3-butenyl)-2,3,3,4,4,5,5-heptamethyl-1-cyclopentene (14): viscous oil. - IR $(\mathrm{KBr}): \tilde{\mathrm{v}}=1644 \mathrm{~cm}^{-1}(\mathrm{C}=\mathrm{N})$. ${ }^{1} \mathrm{H} \mathrm{NMR}\left(\mathrm{CDCl}_{3}\right): \delta=0.69\left(\mathrm{~s}, 3 \mathrm{H}, \mathrm{CH}_{3}\right), 0.75\left(\mathrm{~s}, 3 \mathrm{H}, \mathrm{CH}_{3}\right), 0.76(\mathrm{~s}$, $\left.3 \mathrm{H}, \mathrm{CH}_{3}\right), 0.81\left(\mathrm{~s}, 3 \mathrm{H}, \mathrm{CH}_{3}\right), 0.92\left(\mathrm{~s}, 3 \mathrm{H}, \mathrm{CH}_{3}\right), 0.97\left(\mathrm{~s}, 3 \mathrm{H}, \mathrm{CH}_{3}\right)$, $1.28\left(\mathrm{~s}, 3 \mathrm{H}, \mathrm{CH}_{3}\right), \mathrm{ABX}$ system with $v_{\mathrm{A}}=2.45, v_{\mathrm{B}}=2.63, v_{\mathrm{X}}=4.38$ and $J_{\mathrm{AB}}=13.9, J_{\mathrm{AX}}=4.4, J_{\mathrm{BX}}=9.4 \mathrm{~Hz}\left(3 \mathrm{H}, \mathrm{CH}_{2} \mathrm{CHN}\right), 7.24-7.73$ $(\mathrm{m}, 10 \mathrm{H}$, arom. $\mathrm{H}), 8.18(\mathrm{~s}, 1 \mathrm{H}, \mathrm{N}=\mathrm{CH}) .-{ }^{13} \mathrm{C} \mathrm{NMR}\left(\mathrm{CDCl}_{3}\right)$ : $\delta=10.71\left(\mathrm{q}, \mathrm{CH}_{3}\right), 20.93\left(\mathrm{q}, \mathrm{CH}_{3}\right), 22.69$ (q, $\left.\mathrm{CH}_{3}\right), 23.93\left(\mathrm{q}, \mathrm{CH}_{3}\right)$, 24.30 (q, $\left.\mathrm{CH}_{3}\right), 24.85$ (q, $\left.\mathrm{CH}_{3}\right), 25.59\left(\mathrm{q}, \mathrm{CH}_{3}\right), 35.84\left(\mathrm{t}, \mathrm{CH}_{2}\right), 45.66$ (s, C-4), 49.59, 50.49 (2 s, C-3,5), $75.58(\mathrm{~d}, \mathrm{CH}-\mathrm{N}), 126.74$ (d), 126.94 (d), 128.20 (d), 128.29 (d), 128.41 (d), 130.29 (d), 134.67 (s, C-2), 136.51 (s), $140.46(\mathrm{~s}), 145.18(\mathrm{~s}, \mathrm{C}-1), 158.80(\mathrm{~d}, \mathrm{CH}=\mathrm{N})$ - - MS $(70 \mathrm{eV})$, $m / z(\%): 373$ (7) $\left[\mathrm{M}^{+}\right], 195$ (34), $194(100), 106(21) .-\mathrm{C}_{27} \mathrm{H}_{35} \mathrm{~N}$ : calcd. 373.27695, found 373.27664 (MS).

Diene 8 and 1: According to the general procedure (reaction time $1 \mathrm{~h})$, the reaction of $8(0.0820 \mathrm{~g}, 0.867 \mathrm{mmol}), N$-benzylidenebenzylamine $(0.168 \mathrm{~g}, 0.858 \mathrm{mmol})$, and LDA $(0.94 \mathrm{mmol})$ afforded a mixture of two diastereoisomers of $15(0.213 \mathrm{~g}, 86 \%$ yield $)$ which was separated by preparative LC (RP18; $\mathrm{MeOH})$. The main isomer $15(32 \%)$ was isolated after several LC separations.

6-Methylene-1,3-diphenyl-2-azaspiro[4,4 ]nonane (15): viscous oil. - ${ }^{1} \mathrm{H} \mathrm{NMR}\left(\mathrm{CDCl}_{3}\right): \delta=0.79-1.05(\mathrm{~m}, 1 \mathrm{H}, 9-\mathrm{H}), 1.12-1.38(\mathrm{~m}$, $2 \mathrm{H}, 8-\mathrm{H}), 1.40-1.65(\mathrm{~m}, 1 \mathrm{H}, 9-\mathrm{H}), \mathrm{ABX}$ system with $v_{\mathrm{A}}=1.82$, 
$v_{\mathrm{B}}=2.43, v_{\mathrm{X}}=4.50$ and $J_{\mathrm{AB}}=12.7, J_{\mathrm{AX}}=7.6, J_{\mathrm{BX}}=8.7 \mathrm{~Hz}(3 \mathrm{H}, 3,4-$ H), $1.94-2.42(\mathrm{~m}, 3 \mathrm{H}, 7-\mathrm{H}, \mathrm{NH}), 4.49(\mathrm{~s}, 1 \mathrm{H}, 1-\mathrm{H}), 5.11$ (br. s, $1 \mathrm{H}$, $\left.=\mathrm{CH}_{2}\right), 5.19$ (br. $\left.\mathrm{s}, 1 \mathrm{H},=\mathrm{CH}_{2}\right), 7.12-7.60(\mathrm{~m}, 10 \mathrm{H}$, arom. $\mathrm{H})$. ${ }^{1.3} \mathrm{C} \mathrm{NMR}\left(\mathrm{CDCl}_{3}\right): \delta=22.84(\mathrm{t}, \mathrm{C}-8), 33.67(\mathrm{t}, \mathrm{C}-7), 37.80$ (t, C-9), 52.01 (t, C-4), 56.31 (s, C-5), 59.14 (d, C-3), 71.21 (d, C-1), 104.81 (t, $\left.=\mathrm{CH}_{2}\right), 126.64$ (d), 126.93 (d), 127.42 (d), 127.54 (d), 127.73 (d), 128.26 (d), 141.93 (s), 145.53 (s), 159.80 (s, C-6).

Diene 9 and 1: After a reaction time of $2 \mathrm{~d}, 9(1.6 \mathrm{~g}, 20 \mathrm{mmol})$, $N$-benzylidenebenzylamine $(3.90 \mathrm{~g}, 20 \mathrm{mmol})$, and LDA $(20.5 \mathrm{mmol})$ gave 16 which was isolated by crystallization from ether $\left(-15^{\circ} \mathrm{C}\right)$. Recrystallization from hexane/ether $(80: 20)$ afforded pure 16 (2.59 $\mathrm{g}, 47 \%$ yield) as colorless needles.

7.9-Diphenyl-8-azabicyclo/4.3.0]non-2-ene (16): m.p. (hexane/ ether) $60-62 \mathrm{C} .-{ }^{\prime} \mathrm{H}$ NMR $\left(\mathrm{CDCl}_{3}\right): \delta=1.65(\mathrm{mc}, 1 \mathrm{H}, 5-\mathrm{H})$, $1.75-1.89(\mathrm{~m}, 1 \mathrm{H}, 5-\mathrm{H}), 1.96-2.11(\mathrm{~m}, 2 \mathrm{H}, 4-\mathrm{H}), 2.14-2.32(\mathrm{~m}$, $2 \mathrm{H}, 6-\mathrm{H}, \mathrm{NH}), 2.57(\mathrm{~m}, 1 \mathrm{H}, 1-\mathrm{H}), 3.98\left(\mathrm{~d}, J_{1.9}=8.6 \mathrm{~Hz}, 1 \mathrm{H}, 9-\mathrm{H}\right)$, $4.06\left(\mathrm{~d}, J_{6.7}=6.0 \mathrm{~Hz}, 1 \mathrm{H}, 7-\mathrm{H}\right), \mathrm{AB}$ system with $v_{\mathrm{A}}=5.63, v_{\mathrm{B}}=5.84$ and $J_{\mathrm{AB}}=10.1 \mathrm{~Hz}$, further split by allylic, homoallylic and/or longrange couplings, $(2 \mathrm{H}, 2,3-\mathrm{H}), 7.25-7.60(\mathrm{~m}, 10 \mathrm{H}$, arom. $\mathrm{H}) .-{ }^{13} \mathrm{C}$ NMR $\left(\mathrm{CDCl}_{3}\right): \delta=23.38,24.97(2 \mathrm{t}, \mathrm{C}-4,5), 45.98,47.35$ (2 d, C-1,6), 66.65, 68.06 (2 d, C-7,9), 126.84 (d), 126.90 (d), 127.00 (d), 127.11 (d), 127.19 (d), 127.89 (d), 128.31 (d, two signals overlapped), 143.88 (s), 145.48 (s). - MS (70 eV), m/z (\%): 275 (3) $\left[\mathrm{M}^{+}\right], 195$ (100), 194 (52), 91 (10). $-\mathrm{C}_{20} \mathrm{H}_{21} \mathrm{~N}$ (275.4): calcd. $\mathrm{C} 87.23, \mathrm{H}$ 7.68, N 5.08; found $\mathrm{C} 87.08, \mathrm{H} 7.59, \mathrm{~N} 5.33$.

Diene 10 and 1: Compounds $10(0.770 \mathrm{~g}, 6.66 \mathrm{mmol}), N$-benzylidenebenzylamine $(1.30 \mathrm{~g}, 6.66 \mathrm{mmol})$, and LDA $(8.66 \mathrm{mmol})$ were allowed to react within $3 \mathrm{~d}$ to give crude 17 which was isolated by preparative $\mathrm{LC}\left(\mathrm{Si} 60 ; \mathrm{CH}_{2} \mathrm{Cl}_{2}\right)$. Crystallization from hexane gave pure $17(0.83 \mathrm{~g}, 41 \%$ yield) as colorless needles.

9,11-Diphenyl-10-azabicyclo[6.3.0 Jundec-2-ene (17): m.p. (hexane) $94.5-96^{\circ} \mathrm{C}$. ${ }^{1} \mathrm{H}$ NMR $\left(400 \mathrm{MHz}, \mathrm{CDCl}_{3}\right): \delta=1.09-1.22(\mathrm{~m}$, $1 \mathrm{H}, 5-\mathrm{H}), 1.23-1.38(\mathrm{~m}, 1 \mathrm{H}, 5-\mathrm{H}), 1.40(\mathrm{mc}, 2 \mathrm{H}, 7-\mathrm{H}), 1.73(\mathrm{mc}$, $2 \mathrm{H}, 6-\mathrm{H}), 2.05-2.14(\mathrm{~m}, 2 \mathrm{H}, 4-\mathrm{H}), 2.16(\mathrm{mc}, 1 \mathrm{H}, 8-\mathrm{H}), 2.35$ (br. s, $1 \mathrm{H}, \mathrm{NH}), 3.22(\mathrm{mc}, 1 \mathrm{H}, 1-\mathrm{H}), 3.79\left(\mathrm{~d}, J_{8,9}=10.5 \mathrm{~Hz}, 1 \mathrm{H}, 9-\mathrm{H}\right), 4.29$ (d, $\left.J_{1,11}=3.65 \mathrm{~Hz}, 1 \mathrm{H}, 11-\mathrm{H}\right), \mathrm{AB}$ system with $v_{\mathrm{A}}=5.61, v_{\mathrm{B}}=5.87$ and $\left.J_{\mathrm{AB}}=10.8, J_{1.2}=11.4, J_{3.4}=7.5 \mathrm{~Hz}, 2 \mathrm{H}, 2,3-\mathrm{H}\right), 7.20-7.60(\mathrm{~m}$, $10 \mathrm{H}$, arom. $\mathrm{H}) .-{ }^{13} \mathrm{C} \mathrm{NMR}\left(\mathrm{CDCl}_{3}\right): \delta=25.07,27.94,28.94,30.20$ (4 t, C-4,5,6,7), 48.79 (d, C-8), 55.29 (d, C-1), 67.81, 68.16 (2 d, C9,11), 126.58 (d), 126.65 (d), 127.24 (d), 127.63 (d), 128.23 (d), 128.31 (d), 131.90, 133.06 (2 d, C-2,3), 143.35 (s), 146.55 (s). - MS (70 eV), m/z (\%): 303 (6) [ $\left.\mathrm{M}^{+}\right], 195$ (100), 194 (40), 106 (16), 105 (11), 91 (38). $-\mathrm{C}_{22} \mathrm{H}_{25} \mathrm{~N}$ (303.4): calcd. $\mathrm{C} 87.08, \mathrm{H} 8.30, \mathrm{~N} 4.61$; found C 87.35, H 8.34, N 4.31 .

Diene 11 and 1: Diene $11(0.800 \mathrm{~g}, 6.66 \mathrm{mmol})$ and 1 obtained from $N$-benzylidenebenzylamine $(1.30 \mathrm{~g}, 6.66 \mathrm{mmol})$ and LDA $(8.66$ $\mathrm{mmol})$ were refluxed $(7 \mathrm{~h})$. Compound $18(0.19 \mathrm{~g}, 9 \%)$ was isolated by crystallization from pentane $\left(-60^{\circ} \mathrm{C}\right)$ as colorless crystals.

2,4-Diphenylspiro[3-azabicyclo[3.3.0]oct-7-ene-6, $1^{\prime}$-cyclopentane] (18): m.p. (pentane) $56-57^{\circ} \mathrm{C}$. - ' $\mathrm{H}$ NMR $\left(\mathrm{CDCl}_{3}\right)$ : $\delta=1.36-1.39(\mathrm{~m}, 1 \mathrm{H}), 1.43-1.49(\mathrm{~m}, 6 \mathrm{H}), 1.50-1.70(\mathrm{~m}, 1 \mathrm{H}), 2.10$ (br. s, $1 \mathrm{H}, \mathrm{NH}$ ), 2.73 (t, $J_{5,4}=J_{5.1}=8.9 \mathrm{~Hz}, 1 \mathrm{H}, 5-\mathrm{H}$ ), 3.39 (X part of $\mathrm{ABX}$ system with $J_{\mathrm{AX}}=2.0, J_{\mathrm{BX}}=1.95$, and $J_{5,1}=8.9, J_{2.1}=6.3$ $\mathrm{Hz}, 1 \mathrm{H}, 1-\mathrm{H}), 3.98\left(\mathrm{~d}, J_{2.1}=6.3 \mathrm{~Hz}, 1 \mathrm{H}, 2-\mathrm{H}\right), 4.08\left(\mathrm{~d}, J_{5.4}=8.9 \mathrm{~Hz}\right.$,
$1 \mathrm{H}, 4-\mathrm{H}), \mathrm{AB}$ part of $\mathrm{ABX}$ system with $v_{\mathrm{A}}=5.60, v_{\mathrm{B}}=5.69$ and $J_{\mathrm{AB}}$ $=5.5 \mathrm{~Hz}, 2 \mathrm{H}, 7,8-\mathrm{H}), 7.21-7.55(\mathrm{~m}, 10 \mathrm{H}$, arom. $\mathrm{H}) .-{ }^{13} \mathrm{C} \mathrm{NMR}$ $\left(\mathrm{CDCl}_{3}\right): \delta=23.39,23.82$ (2 t, C-3', $\left.4^{\prime}\right), 32.39,41.86$ (2 t, C-2', $\left.5^{\prime}\right)$, 57.95 (s, C-6), 58.92 (d, C-5), 61.04 (d, C-1), 65.77 (d, C-4), 67.83 (d, C-2), 126.65 (d), 126.86 (d), 127.16 (d), 128.25 (d), 128.30 (d), 128.36 (d), 129.74 (d, C-8), 139.06 (d, C-7), 143.55 (s), 144.85 (s). - MS (70 $\mathrm{eV}), m / z(\%): 315(4)\left[\mathrm{M}^{+}\right], 195$ (100), 194 (36), 143 (23), 91 (16). $\mathrm{C}_{23} \mathrm{H}_{25} \mathrm{~N}$ : calcd. 315.1987 , found 315.19933 (MS).

Kinetic Measurements: The reactions were carried out with equimolar amounts $(1.3 \mathrm{mmol})$ of $\mathbf{1}$ and diene $(7$ or 8$)$ in THF (total volume $10 \mathrm{ml}$ ) in the presence of 1-phenyldodecane (internal standard) according to the standard procedure. After certain periods, $0.5-\mathrm{ml}$ portions of the solution were taken and the reaction was quenched by injection into a $\mathrm{CH}_{3} \mathrm{OH} / \mathrm{H}_{2} \mathrm{O}$ solution. Then the samples were analyzed by GC on a fused silica capillary column SE 30 (length $25 \mathrm{~m}$, i.d. $0.2 \mathrm{~mm}$, carrier $\mathrm{N}_{2}, p=50 \mathrm{kPa}$, column temp. $240 \mathrm{C}$ ). Retention times (area factors) for standard, 13, and 15 were 2.86 (1.0), 20.64 (1.349), and 7.51 (1.489) min, respectively.

" Dedicated to Professor R.W. Hoffmann on the occasion of his 60 th birthday.

(1) R. B. Woodward, R. Hoffmann, Angew. Chem. 1969, 81 797-869; Angew. Chem. Int. Ed. Engl. 1969, 8, 781.

[2] [2a] R. Eidenschink, Th. Kauffmann, Angew. Chem. 1972, 84, 292-293; Angew. Chem. Int. Ed. Engl. 1972, 11, 292-293. ${ }^{[2 b]}$ G. Boche, D. Martens, Angew. Chem. 1972, 84, 768-769; Angew. Chem. Int. Ed. Engl. 1972, 11, 724. - [2c] G. Boche, K. Buckl, D. Martens, D. R. Schneider, H.-U. Wagner, Chem. Ber. 1979, 112, $2961-2966$.

[3] [3a] Th. Kauffmann, E. Koppelmann, Angew. Chem. 1972, 84 261-262; Angew. Chem. Int. Ed. Engl. 1972, 11, 290. - [3b] Review: Th. Kaufmann, Angew. Chem. 1974, 86, 715-750; Angew. Chem. Int. Ed. Engl. 1974, 13, 627.

${ }^{[4]} \mathrm{R}$. Huisgen in 1,3-Dipolar Cycloaddition Chemistry (Ed.: A. Padwa), vol. 1, Wiley, New York, 1984, p. 152.

${ }^{[5]}$ Th. Kauffmann, R. Eidenschink, Angew. Chem. 1971, 83, 794; Angew. Chem. Int. Ed. Engl. 1971, 10, 739; Chem. Ber. 1977, 110, $645-650$.

${ }^{[6]}$ D. J. Bower, M. E. Howden, J. Chem. Soc., Perkin Trans. 1, 1980, $672-674$

[7] [7a] Review: H. Mayr, J. Baran, U. W. Heigl, Gazz. Chim. Ital. 1991, 121, 373-381. - ${ }^{[7 b]}$ H. Mayr, U. W. Heigl, Angew. Chem. 1985, 97, 567-568; Angew. Chem. Int. Ed. Engl. 1985, 24, 579-580. - ${ }^{[7 \mathrm{c}]}$ H. Mayr, U. W. Heigl, J. Chem. Soc., Chem. Commun. 1987, 1804. - [’d] J. Baran, H. Mayr, J. Am. Chem. Soc. 1987, 109, 6519-6521. - [7] J. Baran, H. Mayr, J. Org. Chem. 1989, 54, 5774-5783. - ${ }^{[7]}$ J. Baran, H. Mayr, V. Ruster, F.-G. Klärner, J. Org. Chem. 1989, 54, 5016-5019.

[8] [8a] N. T. Anh, Die Woodward-Hoffmann Regeln und ihre Anwendung, Verlag Chemie, Weinheim, 1972. - ${ }^{[8 \mathrm{~b}]}$ I. Fleming, Frontier Orbitals and Organic Chemical Reactions, Wiley, London, 1976.

[9] J. Baran, H. Mayr, J. Org. Chem. 1989, 54, 5012-5016.

${ }^{[10]}$ J. Baran, H. Klein, C. Schade, E. Will, R. Koschinsky, E. Bäuml, H. Mayr, Tetrahedron 1988, 44, $2181-2184$.

[11] [11i] A. T. Blomquist, J. Wolinsky, Y. C. Meinwald, D. T. Longone, J. Am. Chem. Soc. 1956, 78, 6057-6063. - [1b] J. W. van Straten, J. J. van Norden, T. A. M. van Shaik, G. T. Franke, W. H. de Wolf, F. Bickelhaupt, Recl. Trav. Chim. Pays-Bas 1978, 97, 105-106.

${ }^{[12]}$ C. F. Wilcox Jr., R. R. Craig, J. Am. Chem. Soc. 1961, 83, $3866-3871$

${ }^{[13]}$ H. Mayr, H. Klein, E. Sippel, Chem. Ber. 1983, 116, 3624-3630.

${ }^{144}$ R. Juday, H. Adkins, J. Am. Chem. Soc. 1955, 77, 4559-4564.

[78/93] 